\title{
GEOLOGY
}

UDC 550.423

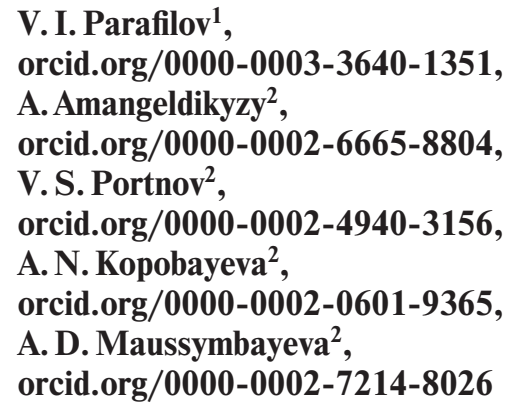

V.I. Parafilov ${ }^{1}$, orcid.org/0000-0003-3640-1351, A. Amangeldikyzy ${ }^{2}$, orcid.org/0000-0002-6665-8804, V.S. Portnov ${ }^{2}$, orcid.org/0000-0002-4940-3156, A. N. Kopobayeva ${ }^{2}$, orcid.org/0000-0002-0601-9365, A. D. Maussymbayeva ${ }^{2}$, orcid.org/0000-0002-7214-8026

https://doi.org/10.33271/nvngu/2020-5/005

1 - "Shubarkol Komir" JSC, Karaganda, the Republic of Kazakhstan

2 - Karaganda State Technical University, Karaganda, the Republic of Kazakhstan, e-mail: amangeldykyzy@inbox.ru

\section{GEOCHEMICAL SPECIALIZATION OF THE SHUBARKOL DEPOSIT COALS}

Purpose. Studying the distribution of impurity elements in the coals of the Shubarkol deposit to assess their geochemical specialization, as well as to forecast their industrial potential.

Methodology. The research methodology is based on the results of analytical studies carried out by the instrumental neutron activation (INAA) method, as well as microscopic studies carried out on the basis of the nuclear-geochemical laboratory of the Department of Geoecology and Geochemistry of National Research Tomsk Polytechnic University. These data became the basis for establishing the patterns of distribution of impurity elements in coals.

Findings. It is found that the coals of the Shubarkol deposit are geochemically specialized in $\mathrm{Ba}, \mathrm{U}, \mathrm{Au}, \mathrm{Yb}, \mathrm{Ba}, \mathrm{Cd}, \mathrm{La}, \mathrm{Nd}$, $\mathrm{Ce}, \mathrm{Zn}, \mathrm{Sc}, \mathrm{Sr}, \mathrm{Zr}$. The weathered coals of the Eastern section of the deposit contain concentrations of $\mathrm{Ce}, \mathrm{Ba}, \mathrm{Yb}, \mathrm{U}, \mathrm{Sc}, \mathrm{Au}$ that are higher than those in the Central and Western sections and reach industrially significant amounts. Recommendations are given for the extraction from the coals of uranium and rare-earth elements of the yttrium group having industrially significant contents.

Originality. Regularities of the impurity elements distribution using the methods of INAA and microscopy are established; the potential of coals as an unconventional source of a number of chemical elements is determined, and the possibility of their complex extraction is evaluated.

Practical value. It consists in substantiating the possibility of the integrated use of coal from the deposit, which ensures the development of the country's coal industry.

Keywords: coal, Shubarkol deposit, impurity elements, average contents, sedimentary rocks

Introduction. In Kazakhstan, more than 300 coal basins and deposits are known. Unique coal resources require an integrated and scientifically based approach to their extraction.

Prediction of the metalliferous content of coal to identify industrially significant concentrations of impurity elements is one of the main tasks of coal geochemistry [1]. In assessing the metal content, the decisive factor is extraction of toxic impurity elements, the presence of which has an effect on mining and their use.

The Shubarkol deposit is located in Central Kazakhstan in the Karaganda region. The coals of the Shubarkol deposit contain a wide range of impurity elements, but they have not received a proper geochemical assessment.

According to previous studies [2], it has been found that it is necessary to assess the reserves of the following elements in coal: boron, vanadium, germanium, gold, copper, nickel, mercury, lead, zinc. At the same time, the germanium content in coal is characterized as the metal content in poor ores. The $\mathrm{Zr}$ content ranges from 63 to $119 \mathrm{~g} / \mathrm{t}$; in the weathering zone, this element amount increases markedly to $138 \mathrm{~g} / \mathrm{t}$ of coal (Belyaev and Pedash, 1989).

Location of the Shubarkol deposit in the tectonic structures of Central Kazakhstan. Central Kazakhstan covers the

(C) Parafilov V. I., Amangeldikyzy A., Portnov V. S., Kopobayeva A. N., Maussymbayeva A. D., 2020 western part of the Ural-Mongolian folded belt, which is a Paleozoic geosynclinal-folded region. The field is confined to the central part of the Sarysu-Tengiz uplift of the block fold zone, a large tectonic structure of the western part of Central Kazakhstan. It is a gentle asymmetric trough of sub-latitudinal strike made by the Lower Jurassic continental deposits, in the context of which there are three coal levels of complex structure with the total working thickness of 5.0 to $47.0 \mathrm{~m}$. It is superimposed on the Upper Paleozoic graben-synclinal of the same name and has a saucer-shaped overall with an almost horizontal bottom and slightly inclined, sometimes steep sides.

Terrigenous-carbonate sediments of the Upper Devonian and Lower Carboniferous, terrigenous rocks of the Middle Upper Carboniferous (Mesozoic deposits), as well as friable Mesozoic weathering products and loose Cenozoic sediments take part in the geological structure of the deposit.

The industrial coal content of the deposit is confined to the lower part of the Jurassic sediment section and contains three coal horizons: Upper, Middle, and Lower.

The Upper Coal Horizon is of greatest interest. It is ubiquitous in the trough, is the most powerful, stable, has a relatively simple structure and is accepted for open development. Within its limits, the center of coal accumulation is clearly distinguished, where the horizon is a single monolithic deposit with an episodically complicated structure in individual mine 
workings. In the center of coal accumulation, the horizon is divided into two coal seams $2 \mathrm{~B}$ and $1 \mathrm{~B}$.

Coals of the Shubarkul deposit belong to mixed type coals: Claren, Duren and Claren-Duren type. Coals are composed mainly of the remains of higher plants, to a lesser extent - of lower ones. The remains of the resulting plants are represented by stem and parenchymal tissues of shrub-herbal plants and are resistant to decomposition by lipoid components - spores, cuticles, resin bodies.

The deposit's coals are distinguished by their low ash content, the presence of impurities of humic acids and rare elements, there are few such coals of the highest purity in nature and this allows us to classify the coals of the deposit as unique.

According to studies carried out at the stage of detailed exploration of the deposit, the list of elements that are expedient to extract includes: beryllium, vanadium, germanium, gold, ytterbium, yttrium, cadmium, lanthanum, lithium, copper, nickel, niobium, mercury, selenium, scandium, strontium, zirconium, since their content is much higher than the clarke one [2].

In order to assess geochemical specialization of coals of the Shubarkol deposit and the industrial potential of impurity elements in the composition of the coals, there has been carried out an instrumental neutron activation analysis (INAA) and microscopic studies.

Research Methodology. The analysis of samples taken at the Shubarkol field was performed using the spot, gross and core sampling methods. Samples of the Central and Western sections were taken by the gross method; the sampling interval was maintained within $15-35 \mathrm{~m}$. The rocks of the western wing of the Central section were tested using the spot method. The rocks of the Eastern section were sampled using the core method, the sampling interval was maintained within 5-20 m. Compounds weighing $200 \mathrm{~g}$ were made of primary core samples, and the group composition of 25 samples from three sections of the field (Central, Western and Eastern) was studied. The samples were studied by instrumental neutron activation analysis (INAA) to determine the average contents of 28 elements: $\mathrm{Sm}, \mathrm{Ce}, \mathrm{Ca}, \mathrm{Lu}, \mathrm{U}, \mathrm{Th}, \mathrm{Cr}, \mathrm{Yb}, \mathrm{Au}, \mathrm{Hf}, \mathrm{Ba}, \mathrm{Sr}, \mathrm{Nd}$, As, Br, Cs, Ag, Tb, Sc, Rb, Fe, Zn, Ta, Co, Na, Eu, La, Sb in the nuclear-geochemical laboratory of the Department of Geoecology and Geochemistry of National Research Tomsk Polytechnic University (TPU) (analyst A.F. Sudyko). The irradiation of samples with the neutron flux was performed at the research nuclear reactor IRT-T of the TPU Physical Technical Institute.

This method has a number of significant advantages in analyzing coal and carbonaceous rocks in comparison with other methods (Gluskoter, et al., 1977; Ruch, et al., 1977; Gofen, et al., 1985; Rikhvanov, et al., 1994; Kizilstein, 2002 and others). The methods of neutron activation analysis are successfully used with the same standard reference samples (SRS) for coal, as well as for coal ash and carbon-bearing rocks. This allows determining the content of chemical elements by one method in various samples, in a wide range (from $n \times 10$ to $\left.n \times 10^{-9} \%\right)$. The absence of chemical sample preparation eliminates errors caused by the introduction or removal of elements together with reagents. Crushing and abrasion of samples is needed only to standardize the process of weighing and packaging samples before irradiation. Since the analytical signal is taken from the nuclei of chemical elements, the physical and chemical state of the sample does not affect the result of the analysis. The effect of changes in the sample matrix composition is determined only by interfering and neutron absorbing elements. It should be noted that carbon and organic compounds in the sample contribute to the improvement of the analysis parameters: they increase accuracy and reduce the limits of detection.

Studying the mineral forms of elements in coals using a Hitachi S-3400N scanning electron microscope (SEM) was carried out at the Uranium Geology Institute at the Depart- ment of Geoecology and Geochemistry of TPU. This method allows identifying and visualizing the mineral forms of micron and nanometer dimensions, as well as determining their elemental composition.

Results. Mineral impurities of all three levels are mainly represented by the pelitomorphic material, which is mainly confined to attritic areas. There are separate lenses of clay substance. Quite often pyrite is found that fills cracks and is present in the form of oolites confined to a gelified substance. In all types of coal, single semi-rounded quartz grains are uniformly distributed in the organic matter.

In the coals of the strata of the Upper and Lower levels, the presence of interlayers saturated with siderite spherulites is characteristic, as a result of which the coals acquire the granular structure. Films of gypsum and kaolinite are noted along the fractures of the formation; calcite filling the cell strips of plant tissues is very rare. The layers of the Upper level are characterized by an unusual mineral association, which presents loose, easily rubbed in the hands oolites ranging in size from 2 to $30 \mathrm{~mm}$, dark brown. Small oolites, confined mainly to semi-brilliant lithotypes of coal, are located in peculiar caverns or leaching voids. They are a pelitomorphic mixture of pyrite, quartz and the amorphous part related to organic matter. Larger oolites, sometimes assembled into splices, are a mixture of organics with fibrous gypsum, in one case, and a weakly cemented organic matter, in the other case. Organics in oolites are mainly represented by gelified matter, less often by small fragments of fusainite and semifusainites. Among the randomly located organics in the gelified substance, circular formations are noted, which are obviously represented by the contents of sporongia. In these formations, the spores are arranged in clear concentric rows, in some cases these rows are somewhat disturbed, the disturbed layer is pushed away from the center, and the spores are distant from each other.

According to the results of the analysis by the INAA method, the average contents of impurity elements in the samples taken in the Eastern section (Fig. 4) are significantly different from the average contents in the samples of the Central and Western sections (Figs. 2, 3). The obtained average contents of impurity elements in the coals of the Central section have predominantly near-clarke values (Table 1, Fig. 1), only some elements (Ce, Ba, Sr, Sc, $\mathrm{Zn}$ ) in individual samples have average contents above the clarke, which is not typical for coals of the Eastern section (Fig. 4).

According to the data obtained, the coals of the Central section are characterized by an almost uniform distribution of impurity elements within the studied formations, where their average contents do not exceed clarke values. However, there are some excesses of clarke contents of $\mathrm{Ba}, \mathrm{Sr}, \mathrm{Ce}, \mathrm{Zn}$ b Sc in single samples.

Below there are graphs of distribution of impurity elements in the coals of the Western section over the 2B (Fig. 2) and 1B (Fig. 3) seams.

The average element contents are calculated separately for each seam. These results were obtained from coal samples taken in accordance with the accepted standards [3].

It follows from the graph that: a) the content of some lithophilic elements $(\mathrm{Ba}, \mathrm{Sb})$ in the Central section is significantly higher compared to the Western section; b) the average contents of almost all of the elements under study in the unoxidized coals of the 1B2 and 2B seams of the Central section are close, which allows concluding that the impurity elements are evenly distributed; c) in the Western section, significantly higher contents of siderophilic (Fe, Co) and chalcophilic ( $\mathrm{Zn}$ ) elements are noted than in the Central in both seams; d) the $\mathrm{Rb}$ content of the $2 \mathrm{~B}$ seam $(3.71$ and $1.48 \mathrm{~g} / \mathrm{t}$ ) is overestimated (2 times compared with the clarke); d) the contents of $\mathrm{Sm}, \mathrm{Ce}$, $\mathrm{Ca}, \mathrm{Cs}, \mathrm{U}, \mathrm{Th}, \mathrm{Cr}, \mathrm{Hf}, \mathrm{Nd}, \mathrm{Br}, \mathrm{Tb}, \mathrm{Sc}, \mathrm{Na}, \mathrm{Eu}, \mathrm{La}$ are equal or close.

In weathered coals from the zone with a high content of uranium in the Eastern section, the concentrations of all the 
The average content of impurity elements in the coals of the Central section

\begin{tabular}{|c|c|c|c|c|c|c|c|c|c|c|c|}
\hline Element & $\begin{array}{c}\text { Sample } \\
\text { No. } 2\end{array}$ & $\begin{array}{c}\text { Sample } \\
\text { No. } 3\end{array}$ & $\begin{array}{c}\text { Sample } \\
\text { No. } 4\end{array}$ & $\begin{array}{c}\text { Sample } \\
\text { No. } 5\end{array}$ & $\begin{array}{c}\text { Sample } \\
\text { No. } 7\end{array}$ & $\begin{array}{c}\text { Sample } \\
\text { No.10 }\end{array}$ & $\begin{array}{c}\text { Sample } \\
\text { No.11 }\end{array}$ & $\begin{array}{c}\text { Sample } \\
\text { No.12 }\end{array}$ & $\begin{array}{c}\text { Sample } \\
\text { No.13 }\end{array}$ & $\begin{array}{c}\text { Sample } \\
\text { No.19 }\end{array}$ & $\begin{array}{l}\text { Clarke } \\
\text { for coal }\end{array}$ \\
\hline $\mathrm{Sm}$ & 0.391 & 0.560 & 0.688 & 1.019 & 0.733 & 0.414 & 0.256 & 0.451 & 0.782 & 0.965 & 1.6 \\
\hline $\mathrm{Ce}$ & 6.92 & 8.17 & 12.83 & 16.93 & 10.58 & 7.02 & 4.65 & 8.81 & 12.52 & 14.31 & 11.5 \\
\hline $\mathrm{Ca}$ & 0.133 & 0.127 & 0.159 & 0.275 & 0.194 & 0.121 & 0.126 & 0.158 & 0.214 & 0.248 & 1 \\
\hline $\mathrm{Lu}$ & 0.058 & 0.048 & 0.056 & 0.118 & 0.083 & 0.065 & 0.048 & 0.058 & 0.093 & 0.108 & 0.07 \\
\hline $\mathrm{U}$ & 0.192 & 0.220 & 0.342 & 0.728 & 0.499 & 0.256 & 0.143 & 0.216 & 0.524 & 0.577 & 1.9 \\
\hline $\mathrm{Th}$ & 0.485 & 0.516 & 0.683 & 1.955 & 1.083 & 0.539 & 0.430 & 0.409 & 1.452 & 1.579 & 3.5 \\
\hline $\mathrm{Cr}$ & 2.29 & 2.40 & 5.29 & 7.06 & 4.39 & 2.01 & 3.61 & 1.79 & 4.87 & 5.45 & 17 \\
\hline $\mathrm{Yb}$ & 0.430 & 0.372 & 0.485 & 0.849 & 0.649 & 0.506 & 0.362 & 0.483 & 0.737 & 0.779 & 0.8 \\
\hline $\mathrm{Au}$ & 0.006 & $<0.002$ & $<0.002$ & 0.001 & $<0.002$ & $<0.002$ & $<0.002$ & $<0.002$ & $<0.002$ & $<0.002$ & 0.002 \\
\hline $\mathrm{Hf}$ & 0.205 & 0.161 & 0.344 & 1.140 & 0.542 & 0.273 & 0.171 & 0.217 & 0.596 & 0.915 & $0.1-0.3$ \\
\hline $\mathrm{Ba}$ & 81.7 & 57.5 & 174.8 & 170.9 & 165.7 & 35.9 & 60.1 & 297.4 & 170.7 & 148.0 & 130 \\
\hline $\mathrm{Sr}$ & 21.5 & 17.8 & 89.4 & 73.2 & 79.2 & 29.9 & $<40$ & 102.4 & 78.9 & 45.6 & 76 \\
\hline $\mathrm{Nd}$ & 3.134 & 2.999 & 4.900 & 6.474 & 3.762 & 3.151 & 2.013 & 5.467 & 5.030 & 6.438 & 30 \\
\hline As & 2.016 & 0.980 & 1.010 & 1.197 & 1.249 & 1.724 & 1.133 & 1.363 & 1.521 & 1.453 & 9 \\
\hline $\mathrm{Ag}$ & $<0.5$ & $<0.5$ & $<0.5$ & $<0.5$ & $<0.5$ & $<0.5$ & $<0.5$ & $<0.5$ & $<0.5$ & $<0.5$ & 0.4 \\
\hline $\mathrm{Br}$ & 0.992 & 2.136 & 0.789 & 1.198 & 0.941 & 0.832 & 1.052 & 1.012 & 0.876 & 0.713 & $5-15$ \\
\hline Cs & 0.002 & 0.513 & 0.246 & 1.473 & 0.593 & 0.330 & 0.074 & 0.100 & 0.753 & 1.233 & $0.4-2$ \\
\hline $\mathrm{Tb}$ & 0.048 & 0.084 & 0.070 & 0.183 & 0.107 & 0.066 & 0.039 & 0.082 & 0.080 & 0.169 & 0.3 \\
\hline Sc & 0.976 & 0.679 & 1.299 & 3.367 & 1.947 & 1.009 & 0.714 & 1.204 & 2.158 & 2.979 & 3 \\
\hline $\mathrm{Rb}$ & $<3$ & 1.47 & 0.87 & 8.68 & 3.17 & 1.72 & 0.23 & $<3$ & 4.24 & 9.29 & 18 \\
\hline $\mathrm{Fe}$ & 0.298 & 0.183 & 0.110 & 0.266 & 0.105 & 0.174 & 0.141 & 0.181 & 0.211 & 0.224 & 1 \\
\hline $\mathrm{Zn}$ & 12.01 & 45.32 & 34.31 & 14.95 & 17.62 & 12.17 & 12.55 & 10.09 & 11.76 & 8.09 & 29 \\
\hline $\mathrm{Ta}$ & $<0.01$ & 0.021 & $<0.01$ & 0.080 & 0.130 & 0.030 & $<0.01$ & $<0.01$ & $<0.01$ & 0.099 & 0.3 \\
\hline $\mathrm{Co}$ & 4.30 & 3.55 & 1.34 & 2.82 & 1.36 & 3.62 & 1.03 & 1.13 & 1.96 & 2.40 & 6.9 \\
\hline $\mathrm{Na}$ & 0.060 & 0.073 & 0.059 & 0.071 & 0.064 & 0.048 & 0.058 & 0.066 & 0.063 & 0.060 & 0.02 \\
\hline $\mathrm{Eu}$ & 0.063 & 0.091 & 0.125 & 0.249 & 0.128 & 0.079 & 0.041 & 0.091 & 0.171 & 0.217 & 0.7 \\
\hline $\mathrm{La}$ & 1.654 & 2.192 & 2.835 & 4.933 & 2.916 & 2.087 & 1.358 & 2.630 & 3.536 & 4.448 & 10 \\
\hline $\mathrm{Sb}$ & 0.061 & 0.073 & 0.107 & 0.174 & 0.158 & 0.096 & 0.083 & 0.091 & 0.183 & 0.132 & 1 \\
\hline
\end{tabular}

* Semi-bold are the average values exceeding the clarke

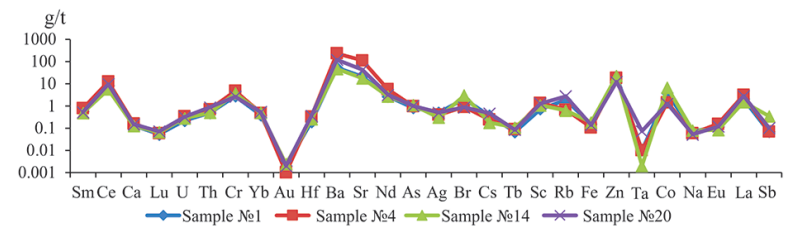

Fig. 1. Distribution of impurity elements in the coal of a $1 B$ seam in the Central section

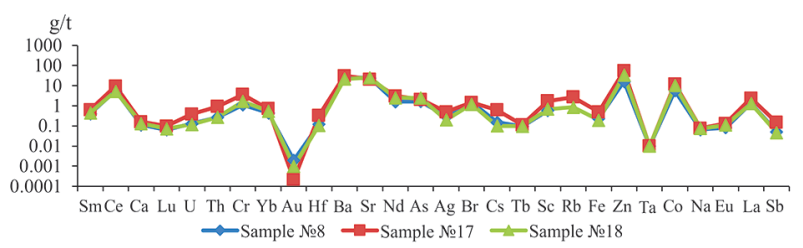

Fig. 2. Graph of distribution of impurity elements in the coal of a 2 B formation in the Western section

rare and rare-earth elements are significantly (5-10 times) higher than in unoxidized coals of the Central and Western sections.

With weathering, in coals the content of humic acids, which are a natural filter for heavy metals due to the addition of metal ions to the free radicals of humic acids, increases significantly (about $1.5-2$ times).

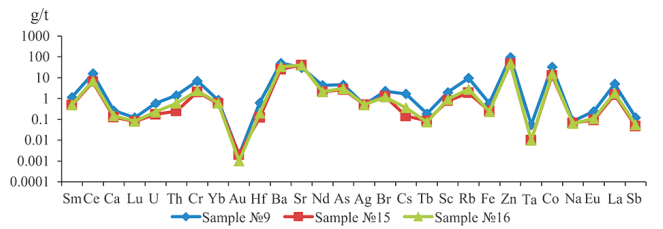

Fig. 3. Graph of distribution of impurity elements in the coal of the formation $1 B$ of the Western section

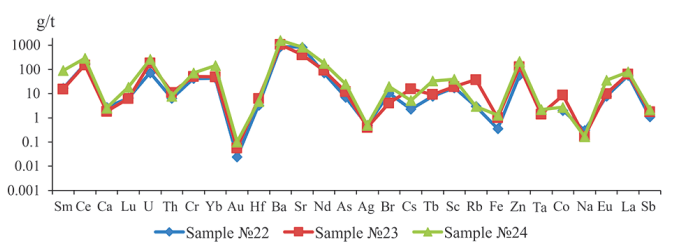

Fig. 4. Graph of distribution of impurity elements in the coals of the Eastern section along the wells 1, 2, 3, g/t

The samples of the Eastern section of the Shubarkol field were taken from the core of wells drilled in the region of the radioactive anomaly, where an increased content of heavy elements is assumed together with uranium [2]. The data obtained from the research results confirmed the presence of high contents of not only heavy elements but light ones as well, such as $\mathrm{Ca}, \mathrm{Cr}, \mathrm{Sc}, \mathrm{Na}$. The average content of elements in 
coals exceeds the clarke values from one to hundreds of times (Fig. 4), thereby reaching industrially significant values $(\mathrm{Ce}$, $\mathrm{Yb}, \mathrm{Ba}, \mathrm{Sr}, \mathrm{Rb}, \mathrm{Co}, \mathrm{U}, \mathrm{Zn}, \mathrm{La}, \mathrm{Nd})$.

The presence in the coals of impurity elements having industrially significant contents is noted in many coal basins and deposits in the world. To assess the potential metal content of the deposit, geochemical specialization of sedimentary rocks was applied, where the chemical composition of the feeding provinces was probably the most important in controlling the composition of sedimentary rocks. The composition of the province's rocks is a function of the geodynamic setting of its formation. Weathering conditions also contribute to the geochemical features of sedimentary rocks, and in some cases when studying the latter it is possible to identify geochemical characteristics associated with this particular factor.

Significant changes in the chemistry of rocks can occur during the transfer and sorption of metals by sedimentary particles: some impurity elements are concentrated in the clay component and in the fraction of heavy minerals with the corresponding depletion of the substantially quartz fraction. This fact is confirmed by high concentrations of impurity elements in the argillite sample taken in the contact zone with coal. Below there is a comparative graph (Fig. 5) that shows the average contents of impurity elements in coals and in the argillite sample of the Eastern section and the clarke values for these elements ( Nd, As, Ag, Br, Sb according to R. L. Rudnick, S. Gao (2003), the others according to I. V. Glukhan, V. I. Serykh (2000)).

From the graph in Fig. 5, it follows that many elements in the mudstone (Sm, Ce, U, Cr, Yb, Ba, Sr, Nd, As, Sc, Zn, Eu, $\mathrm{La}$ ) have average values higher than those in coals of the same section, and also have values that are higher that the clarke ones.

There is distinguished geochemical specialization of the first and second types (Smyslov, 1979). Geochemical specialization of the first type makes it possible to determine the circle of elements that were accumulated in coals in quantities that determine the geochemical background of the element. These include not all the elements that determine geochemical specialization of the framing rocks but only carbonaceous elements that are able to concentrate in large quantities in coal [5].

Volcanic and plutonic complexes surrounding the Shubarkol deposit are predominantly represented by potassium trachidacites, alkaline-feldspar rhyolites, Kalinar granosyenites, andesites, Kalinar granodiorites, quartz diorites, leucogranites and other rocks of volcanic and plutonic accumulations [6] of level $\mathrm{Sc}, \mathrm{Cr}, \mathrm{Fe}, \mathrm{Au}$ ), individual chalcophiles ( $\mathrm{Zn}, \mathrm{Sb}, \mathrm{As}$,), as well as Eu and $\mathrm{U}$ and low contents of most other lithophilic elements as a whole, emphasizing geochemical specialization of coal deposits.

Specialization of the second type indicates the presence of potential industrial contents of elements and is estimated by the method of A. A. Smyslov, where it is determined by comparing the average contents of elements in coals with their average contents in the earth's crust [7]. Specialization of the second type for coals of the Shubarkol deposit was estimated as the ratio of the average contents of elements in coals to re-

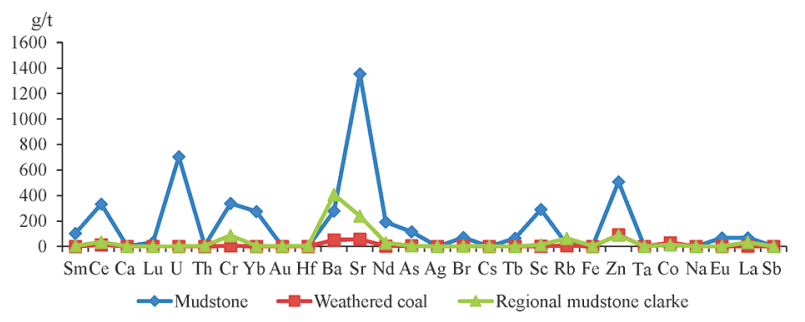

Fig. 5. Graph of the distribution of impurity elements in coals, mudstones of the Eastern section of the Shubarkol deposit gional clarke values calculated by I. V. Glukhan, V. I. Serykh, which clearly correlate with the world clarke values (Vinogradov, 1962; Taylor, McLennan, 1985); at this there are distinguished features of the chemical composition of the studied region rocks [8]. These clarke values (Glukhan, Serykh, 2003) are used in various geochemical and metallogenic studies, as well as in the interpretation of geophysical research data.

The radiogeochemical typing of coal was carried out according to the $\mathrm{Th} / \mathrm{U}$ ratio, which made it possible to isolate radio geochemical fields with a disturbed ratio of radioactive elements. The first field is characterized by coals in which a high content of thorium and an average value of uranium with a Th/U value of 3.0-2.0. The second field is characterized by a high content of thorium and a low value of uranium at a $\mathrm{Th} / \mathrm{U}$ value in the range of $2.0-1.0$. The third field is due to the high uranium content and low thorium content and has a $\mathrm{Th} / \mathrm{U}$ value of $1.0-0.1$.

In the weathered coals of the Shubarkol deposit, uranium concentrations exceed $1000 \mathrm{~g} / \mathrm{t}$, which leads to the need for special disposal or deactivation of weathered coals. At the same time, the uranium content in weathered coals corresponds to the content in poor uranium ores, while uranium will be associated with the main useful component - coal. In this case, it becomes advisable to assess the fundamental possibilities for the extraction of uranium as an associated component.

Microscopic studies carried out on a scanning electron microscope (SEM) Hitachi S-3400N show the presence of mineral inclusions of various compositions. These are inclusions of barite $\left(\mathrm{BaSO}_{4}\right)$, which has angular grains of irregular shape in the form of plates by cleavage (Figs. 6, $a, a^{\prime}$ ), as well as inclusions of sphalerite (Figs. 6, $b, b^{\prime}$ ).

Conclusions. Today, as a result of the increasing demands of the modern market, interest has arisen in associated metals concentrated in coal, in particular rare (including rare-earth) ones. Their highest concentrations are most often localized in weathering crusts, which fully applies to coals.

The second (but at the same time the most widely used and studied) direction of using oxidized coals today is the production of non-fuel products.

The presence in the coals of the deposit of chemical elements and compounds needed for industry involves the search for ways to use them comprehensively. For this, it is necessary to evaluate the coal reserves together with the assessment of impurity elements, to identify the regular relationships between the coal characteristics including dressability and quality of the dressing products [9-11]. The coals of the Shubarkol deposit are specialized in Ba, U, V, Ge, Au, Yb, Cd, La, Li, $\mathrm{Cu}, \mathrm{Ni}, \mathrm{Nb}, \mathrm{Hg}, \mathrm{Se}, \mathrm{Sc}, \mathrm{Sr}, \mathrm{Zr}$. This type of coal specialization is consistent with the general geochemical features of the region's volcanogenic and plutonogenic formations. A high contrast of anomalies of impurity elements allows predicting the formation of coal seams with industrially significant contents of $\mathrm{Ce}, \mathrm{Ba}, \mathrm{Yb}, \mathrm{U}, \mathrm{Sc}, \mathrm{Au}$.

With modern technologies, it is quite possible to develop an economically viable production of extracting impurity elements from coal. The most promising ones for the Shubarkol field are $\mathrm{U}, \mathrm{Sc}, \mathrm{Ba}, \mathrm{Yb}$.

Of the whole spectrum of rare metals analyzed in the weathered coals of the Shubarkol deposit, uranium and rareearth metals are of the greatest industrial interest. The uranium content corresponds to ordinary deposits, in rare-earth metals the ores are also ordinary but with high contents of metals of the yttrium group. The remaining rare metals characterized by high contents in oxidized coal, are not of practical interest at present, since cost-effective technologies of their extraction from coal have not been developed yet and the demand for them is fully provided by ores from deposits of traditional geological and industrial types.

The increased radioactivity of weathered coals limits their use due to the danger of environmental consequences and 


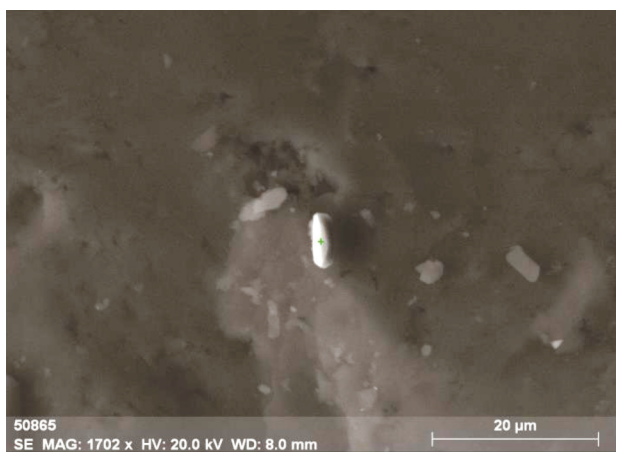

$a$

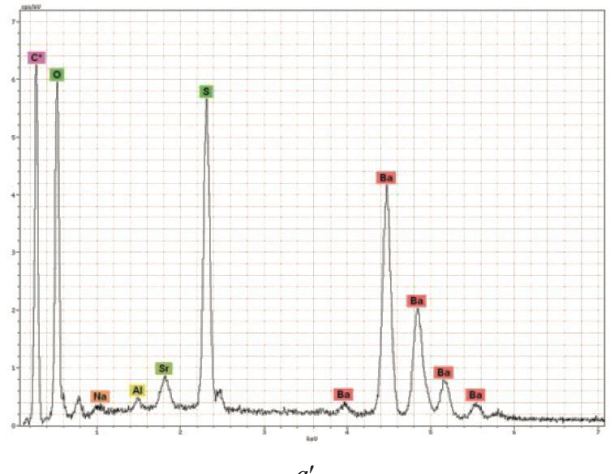

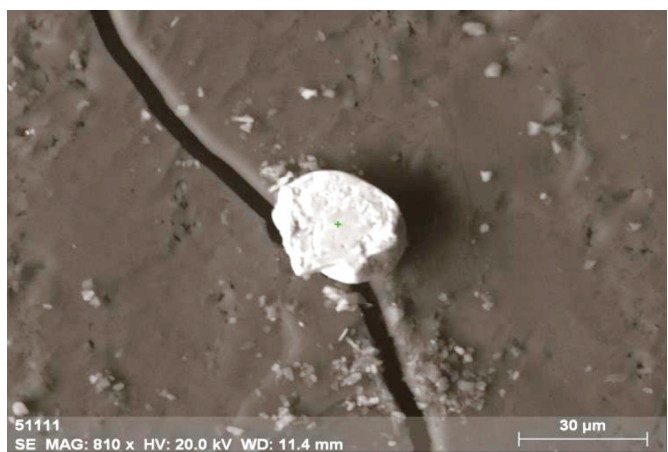

$b$

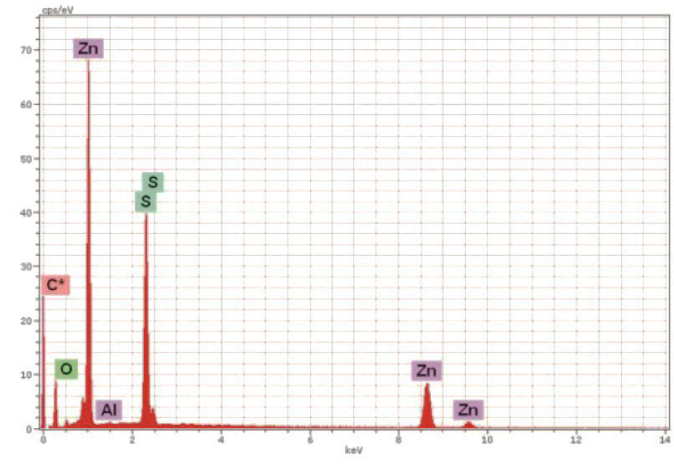

$b^{\prime}$

Fig. 6. The results of microscopic studies:

$a$-inclusion of barite; $a^{\prime}$ - spectrogram; $b$-inclusion of sphalerite; $b^{\prime}$ - spectrogram

therefore requires the extraction of uranium before further processing of coal. The most appropriate technology of extracting uranium from coal is heap leaching.

The traditional trend of dressing weathered coal in uranium and rare-earth metals, the burning of weathered coal together with normal coals seems to be inappropriate, since lowtemperature combustion, which is needed for the concentration of uranium in the ash, decreases the energy output: coal is not burnt and rare earth metals are partly removed in the gas phase. During high-temperature combustion, rare-earth metals are concentrated in ashes and slag but possibly a part of uranium will be lost: released into the atmosphere forming an anthropogenic source of radioactive contamination.

Laboratory experiments on leaching uranium and rareearth metals carried out by the Institute of Mineralogy, Geochemistry, and Crystal Chemistry of Rare Elements (FGBI IMGRE, 2019) showed a low yield of metals in an alkaline solution in a possible process of producing sodium and potassium humates.

Thus, in order to minimize the negative impact on the environment, it is advisable to focus on leaching uranium and rare-earth metals from weathered coals as a process that allows deactivating ore before transferring it for further processing, thermal or chemical.

\section{References.}

1. Arbuzov, S. I., Chekryzhov, I. Yu., Yuzhuang Sun, Cunliang, Zhao, Mashenkin, V.S., Ilyenok, S. S., ..., \& Zarubina, N. V. (2017). Rare-Earth Elements (La, Ce, Sm, Eu, Tb, $\mathrm{Yb}, \mathrm{Lu}$ ) in the Coals of the North Asia (Siberia, Russian Far East, North China, Mongolia, Kazakhstan). Geosphere studies, (4), 6-27 https://doi.org/10.17223/25421379/5/1.

2. Kazhumukhanova, M.Z. (2015). Elements-impurities in coal deposits of Kazakhstan. Problems of geology and subsurface development: proceedings of the XIX International Symposium of Students and Young Scientists named after Academi- cian M.A. Usov dedicated to the $70^{\text {th }}$ anniversary of the Victory of the Soviet People over Nazi Germany, (Vol. 1, pp. 105-106). Tomsk. Publ TPU. Retrieved from http://earchive.tpu.ru/ handle/11683/22690.

3. ISO (2006). ISO 18283:2006 "Hard coal and coke - Manual sampling”, IDT. Retrieved from https://www.iso.org/standard/31776.html.

4. Grunsky, E. C. (2010). The interpretation of geochemical survey data. Geochemistry: Exploration, Environment, Analysis, 10(1), 27-74. https://doi.org/10.1144/1467-7873/09$\underline{210}$.

5. Grigoriev, N.A. (2009). Chemical element distribution in the upper continental crust. Ekaterinburg: UB RAS. ISBN: 978-57691-2083-1.

6. Geological map of Central Kazakhstan. Compiled by Glukhan, I. V., Serykh, V.I., Gridina, N. M., \& Kondrashenkov, I. I. (2007).

7. Arbuzov, S.I., Mashenkin, V.S., Rybalko, V.I., \& Sudyko, A.F. (2014). The rare-metal potential of coals of North Asia (Siberia, the Russian Far East, Kazakhstan, Mongolia) // Noble, rare and radioactive elements in ore-forming systems. Materials of All-Russian scientific conference from the international participation; Rus. Acad. sciences, Sib. Department, Institute of Geology and Mineralogy named after V. S. Sobolev, (pp. 32-36). Novosibirsk: INGG SB RAS. Retrieved from http://shakhov.igm.nsc.ru/pdf/.

8. Portnov, V. S., \& Kopobaev, A. N. (2018). Mo distribution in igneous rocks of Central Kazakhstan. Industry of Kazakhstan, 3(104), 40-44.

9. Popovich, I. N. (2014). Sustainability of the development of the coal industry is a state priority. Naukovyi Visnyk Natsionalnoho Hirnychoho Universytetu, (2), 30-35.

10. Kurmelev, I. I., \& Kurmelev, A. I. (2009). The methodology for predicting the content of rare elements in coal processing products. Naukovyi Visnyk Natsionalnoho Hirnychoho Universytetu, (1), 30-31. 
11. Dai, S., \& Finkelman, R. B. (2018). Coal as a promising source of critical elements: progress and future prospects. International Journal of Coal Geology, 186, 155-164. https://doi. org/10.1016/j.coal.2017.06.005.

\section{Геохімічна спеціалізація вугілля Шубаркольського родовища}

\section{В. I. Парафілов ${ }^{1}$, А. Амангельдіқизи ${ }^{2}$, В. С. Портнов ${ }^{2}$} А. Н. Копобаєва ${ }^{2}$, А. Д. Маусимбаєва

1 - АТ «Шубарколь комір», м Караганда, Республіка Казахстан

2 - Карагандинський державний технічний університет, м Караганда, Республіка Казахстан. e-mail: amangeldykyzy@inbox.ru

Мета. Вивчення розподілу елементів-домішок у вугіллі родовища Шубарколь для оцінки їх геохімічної спеціалізації, а також прогнозу їх промислового потенціалу.

Методика. Методика досліджень базується на результатах аналітичних досліджень, проведених інструментально-нейтронно-активаційний (IHAA) методом, а також мікроскопічних досліджень, проведених на базі ядерно-геохімічної лабораторії кафедри геоекології та геохімії Національного дослідницького Томського політехнічного університету. Ці дані були покладені в основу для встановлення закономірностей розподілу елементівдомішок у вугіллі.

Результати. Встановлено, що вугілля Шубаркольського родовища геохимично спеціалізоване на $\mathrm{Ba}, \mathrm{U}$, $\mathrm{Au}, \mathrm{Yb}, \mathrm{Ba}, \mathrm{Cd}, \mathrm{La}, \mathrm{Nd}, \mathrm{Ce}, \mathrm{Zn}, \mathrm{Sc}, \mathrm{Sr}, \mathrm{Zr}$. Виветреле вугілля Східного ділянки родовища містить концентрації Се, $\mathrm{Ba}, \mathrm{Yb}, \mathrm{U}, \mathrm{Sc} . \mathrm{Au}$ вище, ніж вугілля Центральної та Західної ділянок і досягає рівня промислово значимих. Надані рекомендації шодо вилучення з вугілля родовища урану й рідкоземельних елементів іттриєвої групи, шо мають промислово значимий зміст.

Наукова новизна. Встановлені закономірності розподілу елементів-домішок із використанням методів IНАA й мікроскопії, визначено потенціал вугілля як нетрадиційного джерела ряду хімічних елементів-домішок, а також оцінена можливість їх комплексного вилучення.

Практична значимість. Полягає в обгрунтуванні можливості комплексного використання вугілля родовища, що забезпечує розвиток вугільної галузі країни.

Ключові слова: вугілля, родовище Шубарколь, елементи-домішки, середні вмісту, осадові породи

\section{Геохимическая специализация углей Шубаркольского месторождения}

\author{
В. И. Парафилов ${ }^{1}$, А. Амангельдиқызы ${ }^{2}$, \\ В. С. Портнов ${ }^{2}$, А. Н. Копобаева ${ }^{2}$, \\ А. Д. Маусымбаева ${ }^{2}$
}

1 - АО «Шубарколь комир», г. Караганда, Республика Казахстан

2 - Карагандинский государственный технический университет, г. Караганда, Республика Казахстан. e-mail: amangeldykyzy@inbox.ru

Цель. Изучение распределения элементов-примесей в углях месторождения Шубарколь для оценки их геохимической специализации, а также прогноза их промышленного потенциала.

Методика. Методика исследований базируется на результатах аналитических исследований, проведенных инструментально-нейтронно-активационным (ИНАА) методом, а также микроскопических исследований, проведенных на базе ядерно-геохимической лаборатории кафедры геоэкологии и геохимии Национального исследовательского Томского политехнического университета. Эти данные были положены в основу для установления закономерностей распределения элементов-примесей в углях.

Результаты. Установлено, что угли Шубаркольского месторождения геохимически специализированы на $\mathrm{Ba}, \mathrm{U}$, $\mathrm{Au}, \mathrm{Yb}, \mathrm{Ba}, \mathrm{Cd}, \mathrm{La}, \mathrm{Nd}, \mathrm{Ce}, \mathrm{Zn}, \mathrm{Sc}, \mathrm{Sr}, \mathrm{Zr}$. Выветрелые угли Восточного участка месторождения содержат концентрации $\mathrm{Ce}, \mathrm{Ba}, \mathrm{Yb}, \mathrm{U}, \mathrm{Sc}$. Аu выше, чем угли Центрального и Западного участков и достигают уровня промышленно значимых. Даны рекомендации по извлечению из углей месторождения урана и редкоземельных элементов иттриевой группы, имеюших промышленно значимые содержания.

Научная новизна. Установлены закономерности распределения элементов-примесей с использованием методов ИНАА и микроскопии, определен потенциал углей как нетрадиционного источника ряда химических элементов-примесей, а также оценена возможность их комплексного извлечения.

Практическая значимость. Заключается в обосновании возможности комплексного использования углей месторождения, обеспечивающего развитие угольной отрасли страны.

Ключевые слова: уголь, месторождение Шубарколь, элементы-примеси, средние содержания, осадочные породы

Recommended for publication by D. Yu. Pak. The manuscript was submitted 22.11.19. 